\title{
Conversion of a Conventional Lathe Machine into a Friction Welding Machine and Performing Some Experimental Tests for its Operational Feasibility
}

\author{
Kamran Shah $^{1 \mathrm{a}}$, Hassan Khurshid ${ }^{2}$, Izhar Ul Haq ${ }^{1 \mathrm{~b}}$, Nauman Khurram ${ }^{3}$, Zeeshan Ali ${ }^{4}$ \\ RECEIVED ON 23.04.2019, ACCEPTED ON 03.03.2020
}

\begin{abstract}
In today's manufacturing environment, there is always a need to use cost effective methods and materials for production purposes. Friction welding is one of such method that offers cost effectiveness and high productivity rate as compared to other similar welding processes. Friction welding process has been used widely in the manufacturing world. It is an adjustable and tolerant process that can join most engineering materials. It is a well-established welding process that can produce good quality weldment between similar and dissimilar materials. Due to this flexibility of use of different materials, it has been used in many applications such as aerospace, automotive and other related manufacturing industries etc. The main objective of this research is to study possibility of doing friction-welding on a typical lathe machine instead of doing it on a friction welding machine and also to check the reliability of the welded joint. Conventional Lathe machine was converted into a friction-welding machine by adopting a systematic procedure. The fixture of the attachment was designed, manufactured and installed and different parameters such as applied pressure and spindle rpm were tested in order to achieve the welding joint by friction. The materials used for welding were Stainless Steel 070M20 and Aluminum 2011-T3.
\end{abstract}

Keywords: Friction Welding, Lathe Machine, Ultimate Tensile Strength (UTS), Brinell Hardness Test (BHT)

\section{INTRODUCTION}

$\mathrm{N}$ owadays, welding is one of the most famous ways to join materials together. It is a good choice for joining materials permanently. According to American Welding Society, some fifty (50) different types of welding operations have been catalogued [1]. Some of the most important among them are Metal Inert Gas (MIG) welding [2], Gas Tungsten arc welding (TIG) [3], Arc Welding [4] and friction-welding [5]. Friction welding is a solid-state process in which same or different materials are coalesced by mechanical friction between them. In this process, materials are joined together via mechanical friction that is generated through rotary and translation motion. As a result plastic deformation occurs between materials and they form a permanent joint. Friction welding has been carried among similar metals such as Al alloys [6, 7] and dis-similar metal such as dis-similar AL alloys[8], Mg alloys [9], Steels [10], Al-Mg [11], Al-Steel [12, 13], Al-Cr [14], and $\mathrm{Zn}-\mathrm{Al}$ [15], and Mg-Steel [16].

From literature review, it is found out that a lot of

${ }^{1}$ NCRA-Advanced Robotics and Automation Lab, Department of Mechatronics Engineering, University of Engineering and Technology, Peshawar, Pakistan.

Email: ${ }^{a}$ kamran.shah@uetpeshawar.edu.pk (Corresponding Author), bizhar@uetpeshawar.edu.pk

${ }^{2}$ Department of Mechanical Engineering, King Faisal University, Saudi Arabia. Email: hassankimr@gmail.com

${ }^{3}$ Department of Civil Engineering, University of Engineering and Technology Lahore, Pakistan. Email: nauman@uet.edu.pk

${ }^{4}$ Department of Industrial Engineering and Management, Dawood University of Engineering and Technology, Karachi, Pakistan. Email: zeeshan.ali@ faculty.muet.edu.pk

This is an open access article published by Mehran University of Engineering and Technology, Jamshoro under CC BY 4.0 International License. 
research has been carried out in the field of friction welding since 1950. Strength and hardness of welded joint are the major issues in case of friction welding. Watanabe et al. [17], studied a butt joint formed by friction stir-welding between aluminum alloy and a mild steel plates. It was found that the tensile strength (max) of the joint was $86 \%$ as compared to aluminum alloy plate. Seli et al. [18], investigated the mechanical properties that changed due to thermal effect of friction-welding of two dis-similar metals i.e. aluminum and mild steel. It was reported that welded materials have low hardness and tensile strength as compared to parent materials. Fauzi et al. [19] successfully joined alumina-6061 aluminum alloy by friction welding using modified centre lathe machine. Heat affected zone was more prominent on $2500 \mathrm{rpm}$ as compared to $1250 \mathrm{rpm}$. The bending strength was also greater on joint of $2500 \mathrm{rpm}$ when compared with $1250 \mathrm{rpm}$ joint. Kim et al. [20], considered three friction stir-welding conditions of aluminum die casting alloy due to different tool plunge downforces. Patel et al. [21] investigated the effect of speed of rotation on friction stir-spot welding of AA 5052-H32 and AA6082-T6 Al alloys. The tensile shear strength on $1500 \mathrm{rpm}$ joint was larger than $1070 \mathrm{rpm}$ joint which was further greater than $765 \mathrm{rpm}$. Uzun et al. [22] studied microstructure, fatigue and hardness properties FSW joint of Al 6013-T4 alloy and X5CrNi18-10 stainless-steel. Fatigue properties of Al 6013-T4/stainless steel joints were approximately 30\% lesser than that of the Al 6013-T6 alloy base metal. Panda et al. [23] showed that welded AA 7020 $\mathrm{Al}$ alloy had maximum UTS at rotational speed of $1050 \mathrm{rpm}$ with traverse speed of $95 \mathrm{~mm} / \mathrm{min}$ and having force (axial) of $8 \mathrm{kN}$. Mitelea et al. [24] examined the carbon-enriched layer in the burr of carburized and a volume-hardened steel joint. Higher axial force and friction stroke helps in expulsion of carbon layer. Stainless steel-Al and $\mathrm{Al}-\mathrm{Cu}$ materials were welded successfully by Sahin et al. [25]. Hardness of steel-Al materials near the weld interface was greater than that of base material. Whereas in aluminum-copper joint, hardness of $\mathrm{Al}$ was lower than that of copper near weld area. Ahmed et al. [26] welded Aluminum alloys AA7075-T6 and AA5083H111 using friction stir-welding at constant rotation rate of $300 \mathrm{rpm}$ and different traverse speeds of $50,100,150$, and $200 \mathrm{~mm} / \mathrm{min}$ in similar and dis- similar joints. EBSD was used to study microstructure of base material and welds. Whereas hardness and tensile testing machines were used to study the mechanical properties. Strength and failure analysis of similar and dis-similar friction stir spot welds was done by Garg and Bhattacharya [27]. Effects of different tools were studied on lap shear strength for similar and dissimilar friction stir spot welded joints. Magalhaes et al. [28] provided a perspective on the current development of the Friction Stir Welding (FSW) technology. The industrialization of the technology and related research were assessed by analyzing patent and scientific publications databases. Cheepu et al. [29] investigated to improve the mechanical properties of stainless steel to titanium with aluminum insert metal joints. It was found out that those welds with aluminum insert prohibited formation of brittle intermediate compounds in the interface of weld. Higher tensile properties were attained of such joints.

The main task of this research was to design and manufacture a fixture that could help to perform the friction welding on an ordinary lathe machine. The primary purpose was to construct a low-cost attachment that could do the required job. Friction welding of stainless steel $070 \mathrm{M} 20$ and aluminum 2011-T3 was done after the fixture was installed. Different diameters of steel to steel and aluminum to aluminum were welded and results are presented. In contrast to the normal practice of using hydraulic system to apply pressure, pneumatic system was employed instead.

\section{MATERIALS AND METHODS}

To convert a conventional lathe into the friction welding machine, the most important task is to design a fixture that can connect the pressure applying mechanism to the stationary part of the specimen that has to be welded. To achieve this goal first, an attachment was designed that could be fitted on the ordinary lathe without compromising its operation.

The primary consideration was to make it as rigid as possible as it had to hold the pneumatic cylinder (to apply equal pressure for friction welding process) with its components and the chuck. The fixture had four Mehran University Research Journal of Engineering and Technology, Vol. 40, No.3, July 2021 [p-ISSN: 0254-7821, e-ISSN: 2413-7219] 
parts, base, head, rectangular plates to maintain the height of it and chuck holder. The thickness of the base was $30 \mathrm{~mm}$ with $(500 \times 300) \mathrm{mm}$ of width and length whereas the thickness of the head was $250 \mathrm{~mm}$ with (500 x 300) mm of width and length (Fig. 1-2).
Three rectangular plates were welded together. The thickness of the first and second plate was $200 \mathrm{~mm}$ and for the third plate it was $5 \mathrm{~mm}$. All the plates shared the same width and length i.e., $(300 \times 70) \mathrm{mm}$. They were positioned under the base (Fig. 3).

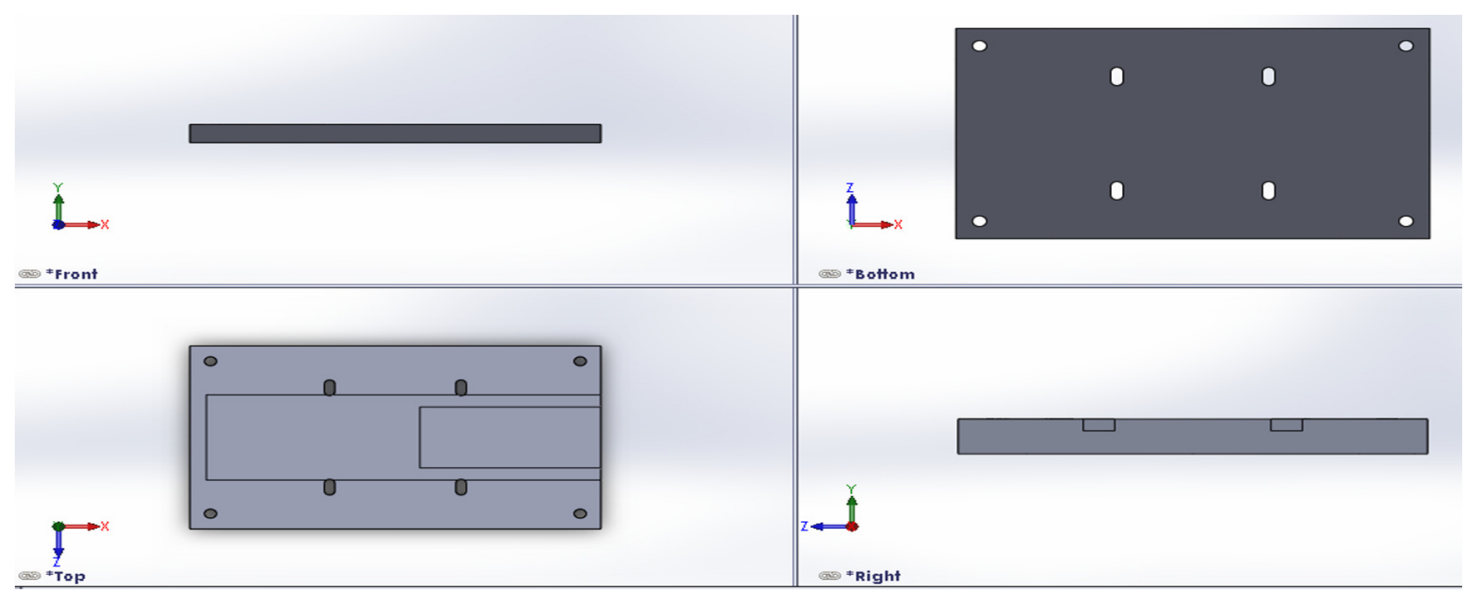

Fig. 1: Base of the fixture

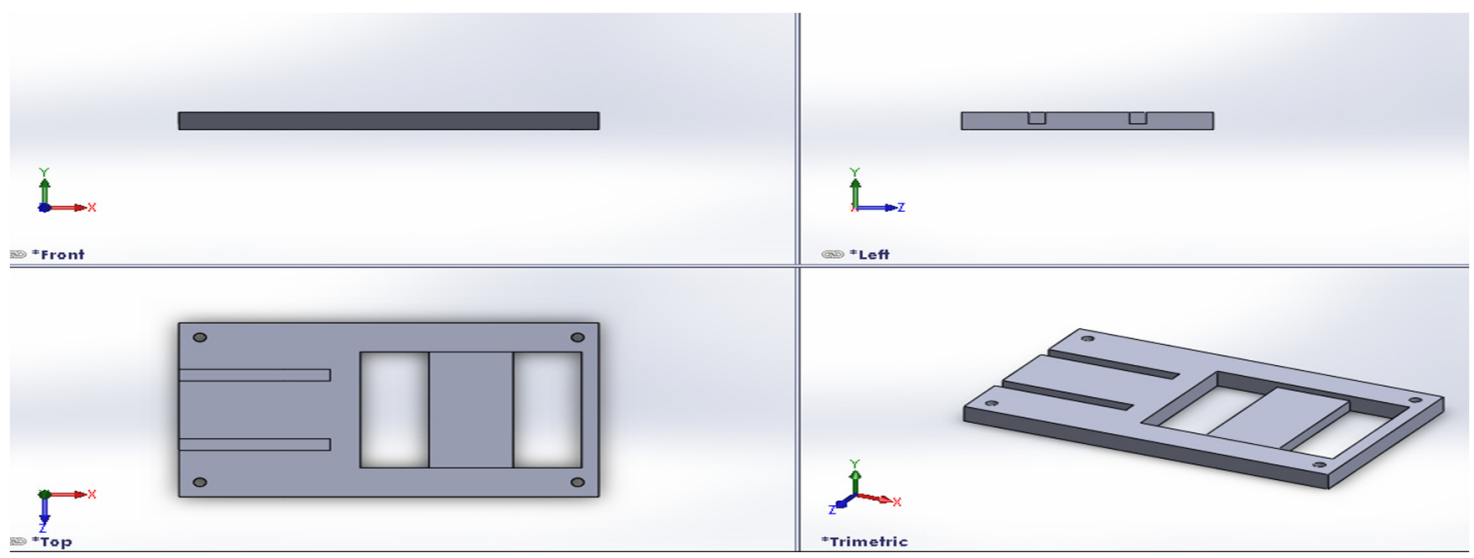

Fig. 2: Head of the fixture

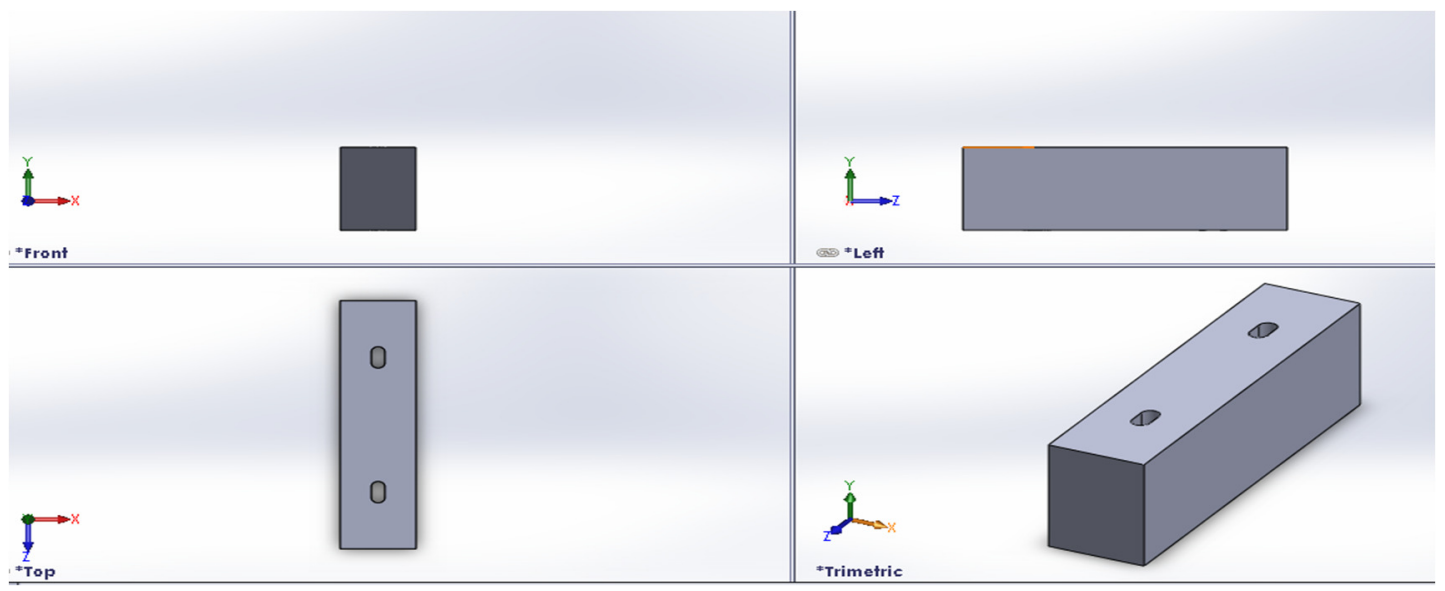

Fig. 3: Rectangular plates 
Chuck holder consisted of a rectangular plate that was connected directly to the cylinder and holding the chuck by using the bolts (Fig. 4). The material used for all the parts of the fixture was SS400 carbon steel. The final fixture design after assembling all the four parts is shown in Fig. 5. The fixture was fixed in the carriage section of the lathe machine as shown in Fig. 6. Fig. 7 shows the installed fixture on the tailstock containing the pneumatic cylinder (to apply pressure) and the chuck on the lathe.

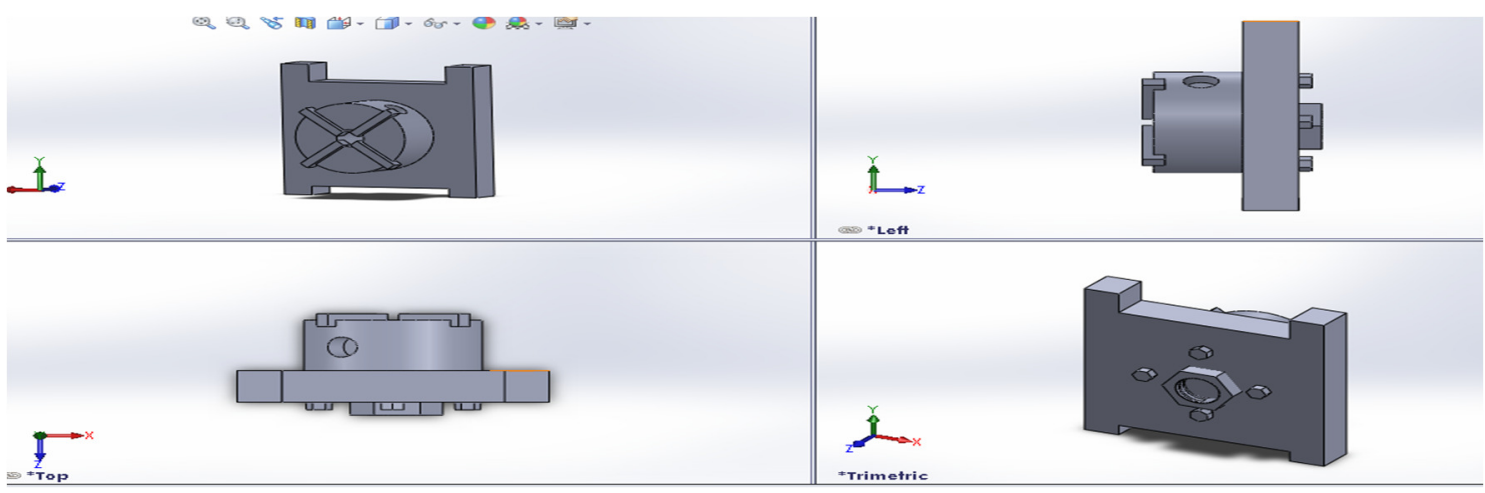

Fig. 4: Chuck holder

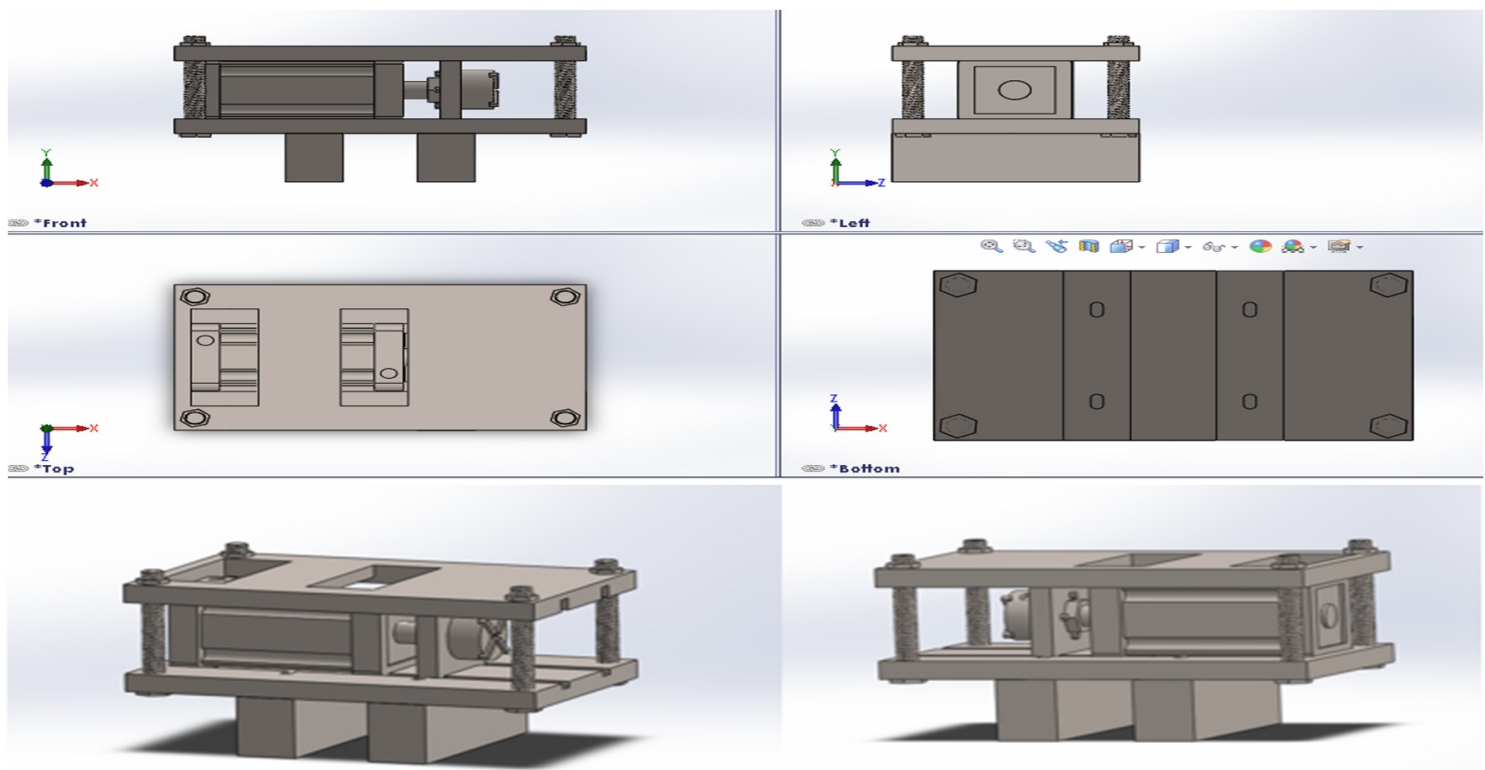

Fig. 5: Fixture assembly

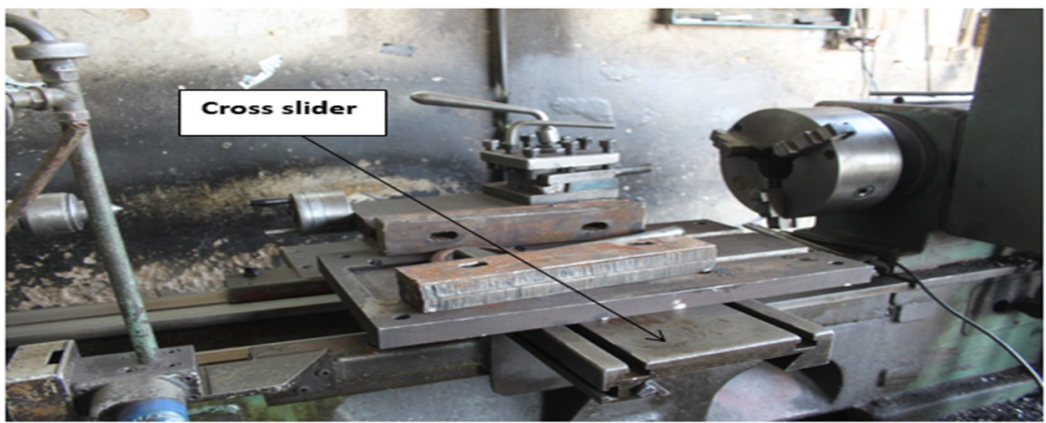

Fig. 6: Cross slider in the lathe machine 


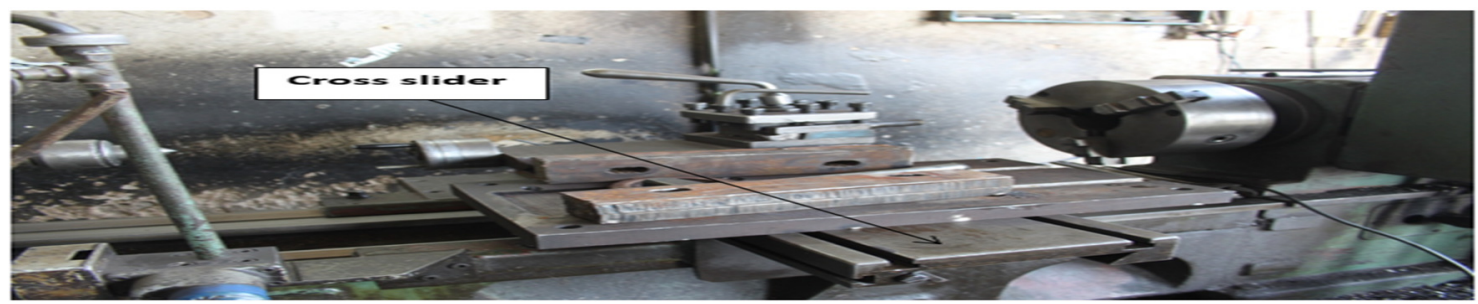

Fig. 7: Final setup of the fixture on the lathe machine

To apply the required pressure, it was decided to choose between hydraulic or pneumatic system. Hydraulic system was disregarded due to its cost and the authors opted for a pneumatic system for this purpose. Easily available pneumatic cylinder in the market worked in the pressure range from $0.5-10$ bar (Fig. 8). There were different designs of the cylinders according to bore and stroke sizes.

At that point, it was hard to judge the capability of the pneumatic system whether it could do the job or not as mostly in the literature, researchers have used hydraulic system for pressure application. A simple experiment was carried out to check this, on the lathe machine. Aluminum was used to make a simple weld and pressure was applied with the hand. It was observed that welding was done successfully. To measure the applied pressure on the specimen, same force was applied by hand on the mass balance to know how much mass was used in the experiment. The mass was about $50 \mathrm{~kg}$. Within the pressure range of the pneumatic cylinder that was between 0.5 and 10 bar, the calculation was done to find out the force that can be provided by the piston. The force was then converted to mass to compare it with experimental mass. For the chosen cylinder specifications (Table 1), the calculation is shown in Table 2.

\begin{tabular}{|l|c|c|c|}
\hline \multicolumn{4}{|c|}{ Table1: Cylinder specifications } \\
\hline Bore & $125 \mathrm{~mm}$ & 0.125 & $\mathrm{~m}$ \\
\hline Area of the piston & 0.012272 & $\mathrm{~m}^{2}$ \\
\hline Stroke & $100 \mathrm{~mm}$ & 10 & $\mathrm{~cm}$ \\
\hline
\end{tabular}

The range of mass after calculation was (62.54 1250.9) $\mathrm{Kg}$ that is higher than experimental mass of $50 \mathrm{~kg}$. It was concluded from this simple calculation that the pneumatic system would do its job correctly by applying any required pressure needed to execute the weld.

\begin{tabular}{|c|c|c|c|c|}
\hline \multicolumn{5}{|c|}{ Table 2: Calculation for cylinder force } \\
\hline \multicolumn{3}{|c|}{ Pressure } & Force & $\mathrm{M}$ \\
\hline Bar & $\mathrm{Mpa}$ & $\mathrm{Pa}$ & $\mathrm{N}$ & $\mathrm{kg}$ \\
\hline 0.5 & 0.05 & 50000 & 613.5923 & 62.54764 \\
\hline 1 & 0.1 & 100000 & 1227.185 & 125.0953 \\
\hline 2 & 0.2 & 200000 & 2454.369 & 250.1905 \\
\hline 3 & 0.3 & 300000 & 3681.554 & 375.2858 \\
\hline 4 & 0.4 & 400000 & 4908.739 & 500.3811 \\
\hline 5 & 0.5 & 500000 & 6135.923 & 625.4764 \\
\hline 6 & 0.6 & 600000 & 7363.108 & 750.5716 \\
\hline 7 & 0.7 & 700000 & 8590.292 & 875.6669 \\
\hline 8 & 0.8 & 800000 & 9817.477 & 1000.762 \\
\hline 9 & 0.9 & 900000 & 11044.66 & 1125.857 \\
\hline 10 & 1 & 1000000 & 12271.85 & 1250.953 \\
\hline
\end{tabular}

After selecting the required pneumatic cylinder, the next task was to how to produce, control and measure the pressure. The pressure was generated from air compressor connected to the double acting pneumatic cylinder (Fig. 8). It is worth mentioning that using pneumatic system for friction welding is limited. The pneumatic cylinder had a diameter of $125 \mathrm{~mm}$ with 100 $\mathrm{mm}$ stroke and could provide pressure up to $1000 \mathrm{kPa}$.

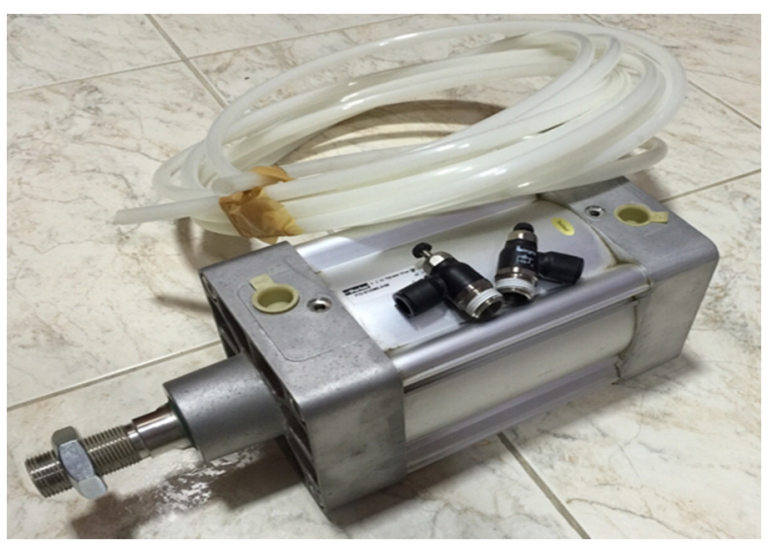

Fig. 8: Double acting pneumatic system.

The cylinder movement was controlled by manual control valve as shown in the Fig. 9. 


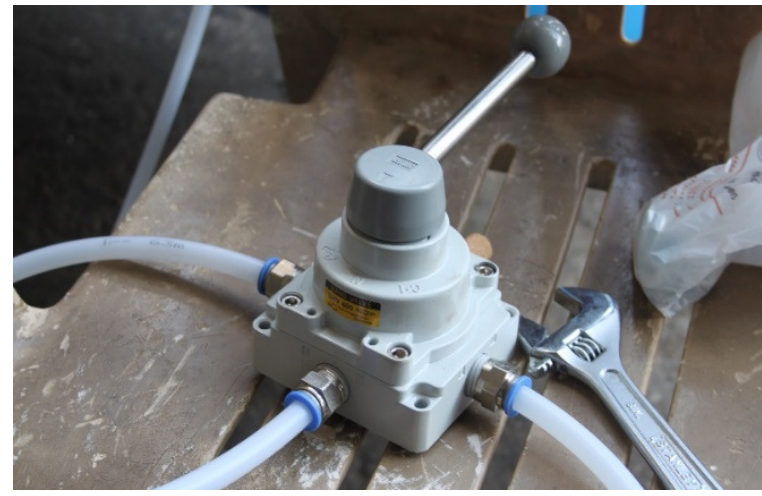

Fig. 9: Manual Control Valve

A pressure gauge (Fig. 10) was installed to take the pressure measurement.

The whole process set-up is shown in Figs. 11 - 12. It can be seen, how the pneumatic cylinder and the control valve are attached to the fixture and how the generated pressure from the air compressor is supplied to the cylinder with the help of pneumatic pipes. This pneumatic system will push one piece of the rod towards the rotating rod connecting to a chuck of the lathe machine that would result in the formation of friction joint between rods.

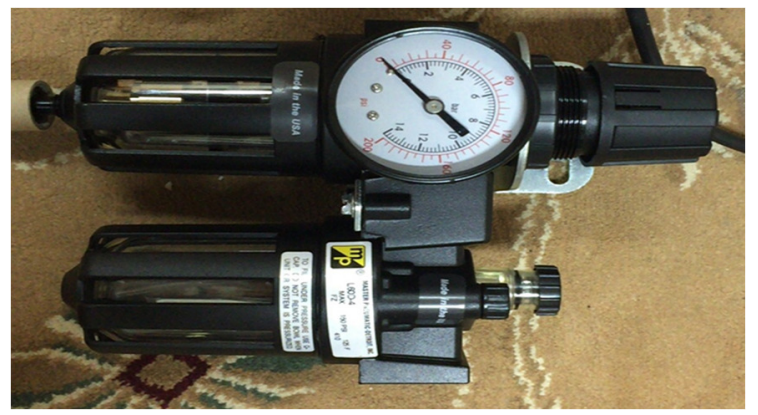

Fig. 10: Pressure Gauge

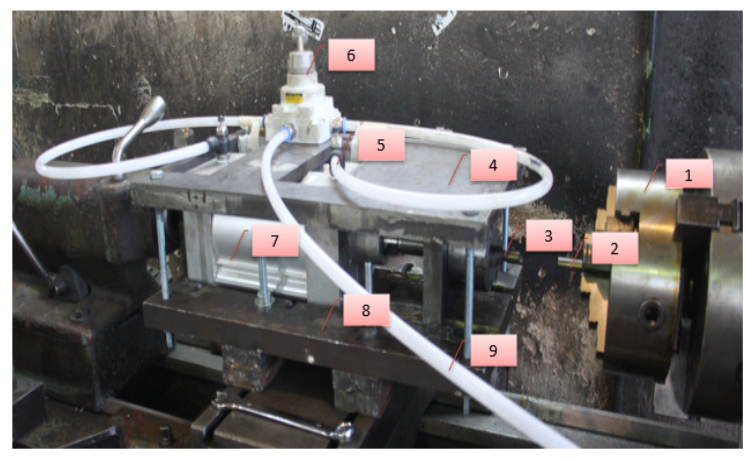

Fig. 11: Process setup (1)

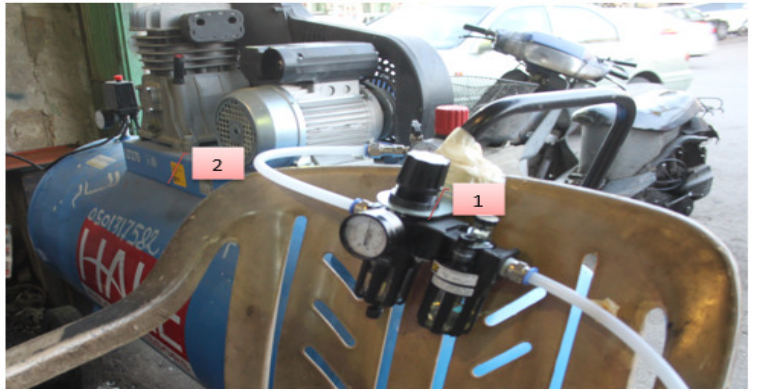

Fig, 12: Process setup (2).

The rotating speed is very critical in the friction welding process. The rotating speed plays a very strong role in increasing the friction and the temperature to cause the material to melt. It is necessary to know the speed of the specimen. The rotating speed was directly noted from the lathe machine that had a range of $1000 \mathrm{rpm}$ to $2000 \mathrm{rpm}$.

\section{RESULTS AND DISCUSSION}

During the welding process, several parameters were tried for both steel and Aluminum having diameters of $10 \mathrm{~mm}$ and $12 \mathrm{~mm}$. Tests were done at three different pressure values $(400,600$ and $800 \mathrm{kPa})$ and at three different rotational speeds (1000, 1400 and $2000 \mathrm{rpm})$. Table 3 and 4 show the parametric values that have been used to perform the friction weld.

Successful welds indicate that the whole exercise of converting an ordinary lathe machine to friction welding machine is fruitful. The cost, being a very primary factor in the design and manufacturing of the system, was also around 160,000 Pak Rupees, which is not much if we compare it with a proper frictionwelding machine. It can be seen at rotational speed of $1000 \mathrm{rpm}$, weld of steel-to-steel was unsuccessful at all the three applied pressures. Aluminum showed entirely opposite behaviour as the machine was not able to weld at $2000 \mathrm{rpm}$ instead of $1000 \mathrm{rpm}$ as that of steel. This observation is interesting, and it shows that both materials show different welding characteristics.

Successful welds were subjected to some mechanical tests. The ultimate tensile strength, fracture point and hardness of the successful welds are shown in Table 5 for both steel and Aluminum joints. 
Conversion of a Conventional Lathe Machine into a Friction Welding Machine and Performing Some Experimental Tests for its Operational Feasibility

\begin{tabular}{|c|c|c|c|c|c|c|}
\hline \multicolumn{7}{|c|}{ Table 3: Experimented parameters for Steel rods } \\
\hline $\begin{array}{c}\text { Test } \\
\text { No. }\end{array}$ & $\begin{array}{c}\text { Diameter } \\
(\mathrm{mm})\end{array}$ & $\begin{array}{c}\text { Pressure } \\
(\mathrm{KPa})\end{array}$ & $\begin{array}{c}\text { Rotational Speed } \\
(\mathrm{RPM})\end{array}$ & $\begin{array}{c}\text { Weld } \\
\text { time(Sec) }\end{array}$ & $\begin{array}{c}\text { Reduction in } \\
\text { length(cm) }\end{array}$ & Condition \\
\hline 1 & 10 & 400 & 1000 & $*$ & $*$ & Unsuccessful \\
\hline 2 & 10 & 600 & 1000 & $*$ & $*$ & Unsuccessful \\
\hline 3 & 10 & 800 & 1000 & $*$ & $*$ & Unsuccessful \\
\hline 4 & 10 & 400 & 1400 & 2.235 & 0.7 & Successful \\
\hline 5 & 10 & 600 & 1400 & 2.615 & 0.7 & Successful \\
\hline 6 & 10 & 800 & 1400 & 2.73 & 0.9 & Successful \\
\hline 7 & 10 & 400 & 2000 & 2.625 & 1.3 & Successful \\
\hline 8 & 10 & 600 & 2000 & 2.705 & 1.4 & Successful \\
\hline 9 & 10 & 800 & 2000 & 3.445 & 1.5 & Successful \\
\hline 10 & 12 & 400 & 1000 & $*$ & $*$ & Unsuccessful \\
\hline 11 & 12 & 600 & 1000 & $*$ & $*$ & Unsuccessful \\
\hline 12 & 12 & 800 & 1000 & $*$ & $*$ & Unsuccessful \\
\hline 13 & 12 & 400 & 1400 & 2.445 & 0.6 & Successful \\
\hline 14 & 12 & 600 & 1400 & 2.25 & 0.5 & Successful \\
\hline 15 & 12 & 800 & 1400 & 2.55 & 0.4 & Successful \\
\hline 16 & 12 & 400 & 2000 & 2.915 & 0.9 & Successful \\
\hline 17 & 12 & 600 & 2000 & 2.93 & 0.7 & Successful \\
\hline 18 & 12 & 800 & 2000 & 3.545 & 0.8 & Successful \\
\hline
\end{tabular}

\begin{tabular}{|c|c|c|c|c|c|c|}
\hline \multicolumn{7}{|c|}{ Table 4: Experimented parameters for Aluminum rods. } \\
\hline $\begin{array}{c}\text { Test } \\
\text { No. }\end{array}$ & $\begin{array}{c}\text { Diameter } \\
(\mathrm{mm})\end{array}$ & $\begin{array}{c}\text { Pressure } \\
(\mathrm{KPa})\end{array}$ & $\begin{array}{c}\text { Rotational Speed } \\
(\mathrm{RPM})\end{array}$ & $\begin{array}{c}\text { Weld } \\
\text { time(Sec) }\end{array}$ & $\begin{array}{c}\text { Reduction in } \\
\text { length }(\mathrm{cm})\end{array}$ & Condition \\
\hline 1 & 10 & 200 & 1000 & 11.78 & 0.2 & Successful \\
\hline 2 & 10 & 400 & 1000 & 2.87 & 0.3 & Successful \\
\hline 3 & 10 & 600 & 1000 & 3.785 & 0.4 & Successful \\
\hline 4 & 10 & 200 & 1400 & 3.955 & 0.7 & Successful \\
\hline 5 & 10 & 400 & 1400 & 2.735 & 1.5 & Successful \\
\hline 6 & 10 & 600 & 1400 & 2.945 & 1.2 & Successful \\
\hline 7 & 10 & 200 & 2000 & $*$ & $*$ & Unsuccessful \\
\hline 8 & 10 & 400 & 2000 & $*$ & $*$ & Unsuccessful \\
\hline 9 & 10 & 600 & 2000 & $*$ & $*$ & Unsuccessful \\
\hline 10 & 12 & 200 & 1000 & 12.13 & 0.2 & Successful \\
\hline 11 & 12 & 400 & 1000 & 8.55 & 0.9 & Successful \\
\hline 12 & 12 & 600 & 1000 & 4.115 & 0.3 & Successful \\
\hline 13 & 12 & 200 & 1400 & 4.645 & 0.2 & Successful \\
\hline 14 & 12 & 400 & 1400 & 4.02 & 1.7 & Successful \\
\hline 15 & 12 & 600 & 1400 & 5.57 & 2.9 & Successful \\
\hline 16 & 12 & 200 & 2000 & $*$ & $*$ & Unsuccessful \\
\hline 17 & 12 & 400 & 2000 & $*$ & $*$ & Unsuccessful \\
\hline 18 & 12 & 600 & 2000 & $*$ & $*$ & Unsuccessful \\
\hline
\end{tabular}

\subsection{Effect of applied pressure on Material Strength}

The mechanical properties of a weld joints changes with changing the parameters during welding. It is concluded that some specimens have excellent mechanical properties due to proper selection of parameters. The stress strain diagram gave valuable information about the strength. One of the factors that must be considered in friction welding is the applied pressure. An accurate selection of the pressure can make excellent mechanical properties. Fig. 13 shows pressure effect on UTS of the steel. Both the diameter and the rotational speed during friction welding were fixed. The diameter and rotational speed was $10 \mathrm{~mm}$ Mehran University Research Journal of Engineering and Technology, Vol. 40, No.3, July 2021 [p-ISSN: 0254-7821, e-ISSN: 2413-7219] 
Conversion of a Conventional Lathe Machine into a Friction Welding Machine and Performing Some Experimental Tests for its Operational Feasibility

\begin{tabular}{|c|c|c|c|c|c|c|}
\hline \multicolumn{7}{|c|}{ Table 5: Welded joints properties } \\
\hline Weld type & $\begin{array}{c}\text { UTS } \\
(\mathrm{MPa})\end{array}$ & $\begin{array}{c}\text { Fracture } \\
\text { Strength } \\
(\mathrm{MPa})\end{array}$ & BHN & Weld type & $\begin{array}{c}\text { UTS } \\
(\mathrm{MPa})\end{array}$ & $\begin{array}{c}\text { Fracture } \\
\text { Strength } \\
(\mathrm{MPa})\end{array}$ \\
\hline SD10P400N1400 & 954.38 & 506.27 & 246.8 & AD10P200N1000 & 291.45 & 163.74 \\
\hline SD10P600N1400 & 1063.08 & 590.270 & 225.3 & AD10P400N1000 & 309.57 & 170.26 \\
\hline SD10P800N1400 & 1000.74 & 548.98 & 204.7 & AD10P600N1000 & 247.20 & 128.31 \\
\hline SD10P400N2000 & 815.41 & 481.58 & 99.3 & AD10P200N1400 & 324.89 & 179.35 \\
\hline & & & & & & \\
\hline SD10P600N2000 & 921.90 & 514.79 & 94.6 & AD10P400N1400 & 275.73 & 150.95 \\
\hline SD10P800N2000 & 951.08 & 543.02 & 166.1 & AD10P600N1400 & 298.07 & 154.68 \\
\hline SD12P400N1400 & 827.49 & 470.66 & 254.8 & AD12P200N1000 & 251.14 & 143.38 \\
\hline SD12P600N1400 & 802.96 & 468.88 & 239.6 & AD12P400N1000 & 260.04 & 134.14 \\
\hline SD12P800N1400 & 711.71 & 411.61 & 237.4 & AD12P600N1000 & 301.75 & 153.04 \\
\hline SD12P400N2000 & 615.43 & 354.67 & 234.1 & AD12P200N1400 & 129.12 & 78.39 \\
\hline SD10P600N2000 & 760.53 & 438.98 & 259.5 & AD10P400N1400 & 270.53 & 144.54 \\
\hline SD10P800N2000 & 552.69 & 300.99 & 231 & AD10P600N1400 & 140.96 & 71.60 \\
\hline
\end{tabular}

*SD10P400N1400 stands for steel-to-steel weld with 10 as thickness of the material used with applied pressure of $400 \mathrm{kPa}$ and rotational speed of $1400 \mathrm{rpm}$. AD stands for Aluminum-to-Aluminum weld. Same convention as mentioned here can be used to identify the weld type.

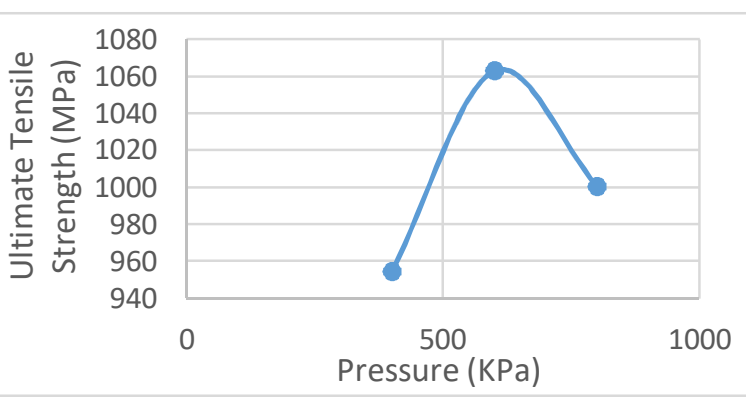

Fig 13: Effect of pressure on the UTS for steel

and $1400 \mathrm{rpm}$ respectively. The only variable was the applied pressure. As shown, the maximum ultimate tensile strength was achieved at a pressure of $600 \mathrm{KPa}$. For Aluminum, with a diameter of $10 \mathrm{~mm}$ and spindle speed of $1400 \mathrm{rpm}$, the maximum UTS was for the weld at a pressure of $200 \mathrm{kpa}$ as shown in Fig. 14.

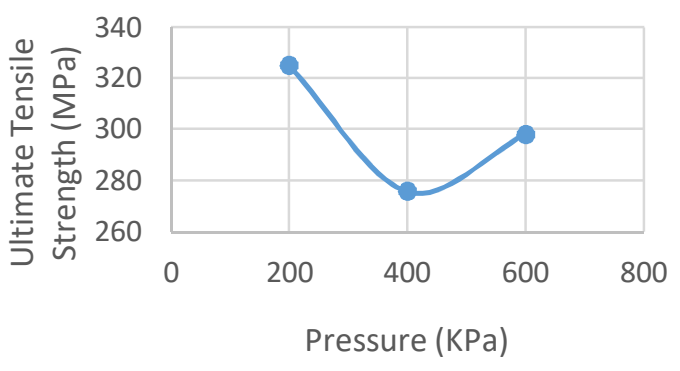

Fig 14: Effect of pressure on the UTS for Aluminum

\subsection{Effect of applied pressure on Material Hardness}

Hardness is an important property that can tell more about the mechanical properties of the joint. Hardness test is done to the welded joint to assess hardness of the joint. Type of hardness test was Brinell Hardness Number (BHN).

The Fig. 15 shows the change in hardness number with applied pressure during welding. The diameter and the rotational speed were fixed i.e. $10 \mathrm{~mm}$ and 1400rpm respectively. The hardness of the material was decreasing with increasing pressure. To have harder material, the pressure should be less.

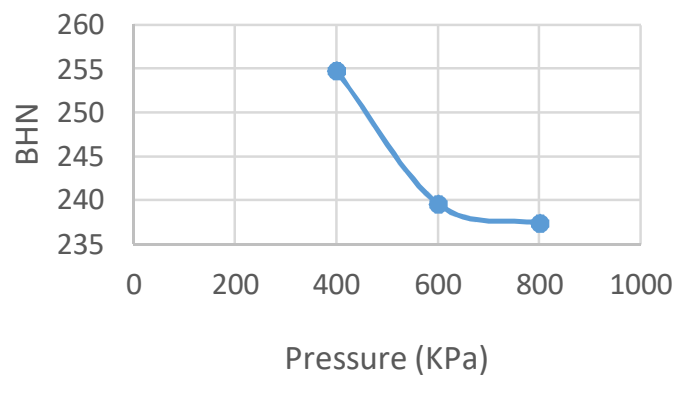

Fig 15: Effect of Pressure on hardness for steel 


\subsection{Effect of spindle speed on Material Strength}

Rotational speed is the main parameter that must be considered during friction welding. Fig. 16 displays the rotational speed effect on ultimate tensile strength of steel. The maximum tensile strength of the welded joint was recorded at a rotational speed of $1400 \mathrm{rpm}$.

\subsection{Effect of spindle speed on Material Hardness}

The material hardness property also changes with change in spindle speed. Fig. 17 indicates the influence of rotational speed to the material hardness of steel. The maximum BHN was for the weld at $1400 \mathrm{rpm}$.

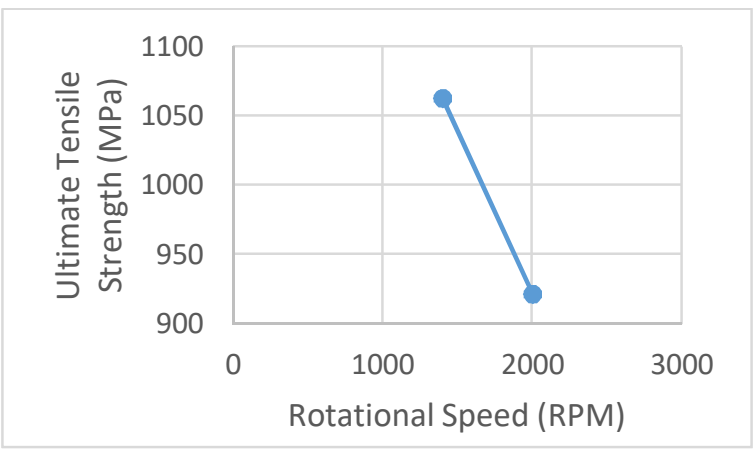

Fig. 16: Effect of speed on the UTS for steel

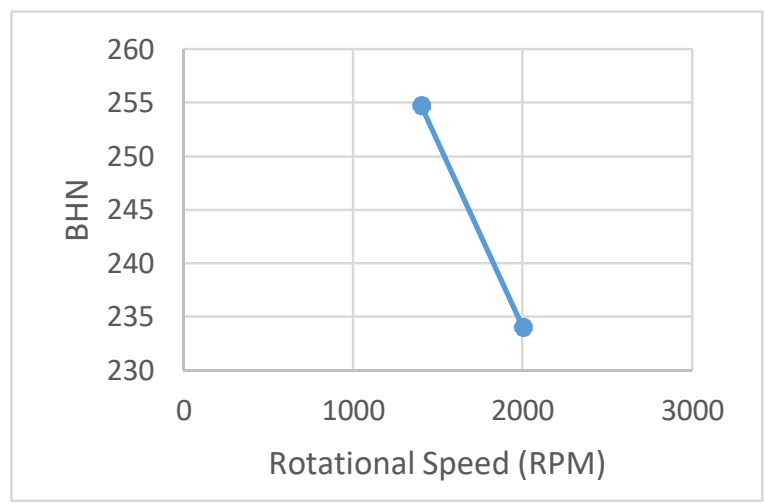

Fig. 17: Effect of speed on hardness for steel

\section{CONCLUSIONS}

Friction welding of Stainless Steel 070M20 and Aluminum 2011-T3 rods is done in this work. The main purpose of the study was to convert a conventional lathe machine in to friction welding machine by keeping the cost to minimum. The task was achieved and the whole process is discussed in detail. In addition, pneumatic system was used in contrast to the hydraulic system in this work, which also contributed to the low cost of the machine. After the conversion, different tests were performed to check the operation of the machine. Diameters of $10 \mathrm{~mm}$ and $12 \mathrm{~mm}$ rods were welded in this research. One rod was placed in the chuck of lathe machine whereas the other was connected to pneumatic cylinder that was fixed to the tailstock of a lathe machine with the help of the designed attachment. It was demonstrated that the machine was able to perform successful welding to the similar material rods. In future, the same set-up will be used to perform welding on the dissimilar materials.

\section{REFERENCES}

1. Groover M.P., "Funadaments of Modern Manufacturing: Materials, Processes and Systems", John Wiley \& Sons, 2007.

2. Wang F., Hou W.K., Kannatey-Asibu, E., Schultz, W.W., and Wang, P.C., et al., "Modelling and analysis of metal transfer in gas metal arc welding", Journal of Physics D: Applied Physics, Vol. 36 No. 9, pp. 1143, 2003.

3. Juang S., Tarng Y., "Process parameter selection for optimizing the weld pool geometry in the tungsten inert gas welding of stainless steel", Journal of Materials Processing Technology, Vol. 122, No. 1, pp. 33-37, 2002.

4. Lloyd R.D., Mitchel D.B., :Electric Arc Welding", Google Patents, 1997.

5. Mishra R.S., Ma Z., "Friction stir welding and processing", Materials Science and Engineering: R: Reports, Vol. 50, No.1, pp. 1-78, 2005.

6. Mitlin D., Radmilovic V., Pan T., Chen J., "Structure-properties relations in spot friction welded (also known as friction stir spot welded) 6111 Aluminum", Materials Science and E\#ngineering: A, Vol. 441, No.1-2, pp. 79-96, 2006.

7. Buffa G., Fratini L., Piacentini M., "On the influence of tool path in friction stir spot welding of Aluminum alloys", Journal of Materials Processing Technology, Vol. 208, Vol. 1, pp. 309317, 2008.

8. Liu X., Lan S., Ni J., "Analysis of process parameters effects on friction stir welding of dissimilar aluminum alloy to advanced high Mehran University Research Journal of Engineering and Technology, Vol. 40, No.3, July 2021 [p-ISSN: 0254-7821, e-ISSN: 2413-7219] 
strength steel", Materials and Design, Vol. 59, pp. 50-62, 2014.

9. Yamamato M., Gerlich A.P., North T.H., Shimozaki K., "Cracking in the stir zones of Mgalloy friction stir spot welds", Journal of Materials Science, Vol. 42, No. 18, pp. $7657-$ 7666, 2007.

10. Khan M., Kuntz M.L., Su P., Gerlich A., North T., Zhou Y., "Resistance and friction stir spot welding of DP600: a comparative study", Science and Technology of Welding and Joining, Vol. 12, No. 2, pp.175-182, 2013.

11. Suhuddin U., Fischer V., Kroeff F., Dos Santos J.F., "Microstructure and mechanical properties of friction spot welds of dissimilar AA5754 Al and AZ31 Mg alloys", Materials Science and Engineering: A, Vol. 590, pp. 384-389, 2014.

12. Habibnia M., Shakeri, M., Nourouzi, S., and Givi, M.K.B., "Microstructural and mechanical properties of friction stir welded $5050 \mathrm{Al}$ alloy and 304 stainless steel plates", The International Journal of Advanced Manufacturing Technology, Vol. 76, No. 5-8, pp. 819-829, 2015.

13. Ma H., Qin G., Geng P., Li F., Microstructure characterization and properties of carbon steel to stainless steel dissimilar metal joint made by friction welding", Materials and Design, Vol. 86, pp. 587-597, 2015.

14. Moshwan R., Yusof F., Hassan M.A., Rahmat S.M., "Effect of tool rotational speed on force generation microstructure and mechanical properties of friction stir welded Al-Mg-Cr-Mn (AA 5052-O) alloy", Materials and Design, Vol. 66, pp. 118-128, 2015.

15. Dong H., Hu W., Duan Y., Wang X., "Dissimilar metal joining of Aluminum alloy to galvanized steel witl $\mathrm{Al}-\mathrm{Si}, \mathrm{Al}-\mathrm{Cu}, \mathrm{Al}-\mathrm{Si}-\mathrm{Cu}$ and $\mathrm{Zn}-\mathrm{Al}$ filler wires", Journal of Materials Processinh Technology, Vol. 212, No.2, pp. 458-464, 2012.

16. Lee C.-Y., Choi D.H., Yeon Y.M., Jung S.B., "Dissimilar friction stir spot welding of low carbon steel and Al-Mg alloy by formation of IMCs", Science and Technology of Welding and Joining, Vol. 14, No. 3, pp. 216-220, 2013.

17. Watanabe T.H., Takayama H., Yanagisawa A., "Joining of Aluminum alloy of steel by friction stir welding", Journal of Materials Processing Technology, Vol. 178, No.1, pp. 342-349, 2006.
18. Seli H., Ismail A.I.M., Rachman E., Ahmad Z.A., "Mechanical evaluation and thermal modelling of friction welding of mild steel and aluminum", Journal of Materials Processing Technology, Vol. 210, No. 9, pp. 1209-1216, 2010.

19. Fauzi M.A., Basheer U.M., Zuhailawati H., Ismail M.B., Microstructure and mechanical properties of alumina-6061 aluminum alloy joined by friction welding", Materials and Design, Vol. 31, No.2, pp. 670-676, 2010.

20. Kim Y., Fujii H., Tsumura T., Komazaki T., Nakata K., "Three defect types in friction stir welding of aluminum die casting alloy", Materials Science and Engineering: A., Vol. 415, No.1, pp. 250-254, 2006.

21. Patel V.V., Sejani D.J., Patel N.J., Vora J.J., Gadhvi B.J., Padodara N.R., Vamja C.D., "Effect of tool rotation speed on friction stir spot welded AA5052-H32 and AA6082-T6 dissimilar aluminum alloys", Metallography, Microstructure and Analysis, Vol. 5, No.2, pp. 142-148, 2016.

22. Uzun H., Donne C.D., Argagnotto, A., and Gambaro, C., "Friction stir welding of dissimilar Al 6013-T4 to X5CrNi18-10 stainless steel", Materials and Design, Vol. 26, 26, No. 1, pp. 4146, 2005.

23. Panda B., Garg A., Jian Z., Heidarzadeh, A., and Gao, L., "Characterization of the tensile properties of friction stir welded aluminum alloy joints based on axial force, traverse speed, and rotational speed", Frontiers of Mechanical Engineering, Vol. 11, No. 3, pp. 289-298, 2016.

24. Mitelea I., Craciunescu C., "Parameter influence on friction welding of dissimilar surfacecarburized/volume-hardened alloyed steels", Materials and Design, Vol. 31, No. 4, pp. 21812186, 2010.

25. Sahin M., Misirli C., "Mechanical and Metalurgical Properties of Friction Welded Aluminium Joints", Aluminium Alloys - New Trends in Fabrication and Applications, Intechopen Publishers. 2012.

26. Ahmed M.M.Z., Ataya S., Seleman M.M.E., Ammar, H.R., and Ahmed, E., "Friction stir welding of similar and dissimilar AA7075 and AA5083", Journal of Materials Processing Technology, Vol. 242, pp. 77-91, 2017.

27. Garg A., Bhattacharya A., "Strenght and failure 
analysis of similar and dissimilar friction stir spot welds: Influence of different tools and pin geometries", Materials and Design, Vol. 127, pp. 272-286, 2017.

28. Magalhaes V.M., Leitao C., Rodrigues D.M., "Friction stir welding industrialization and research status", Science and Technology of Welding and Joining, 23(5): pp. 400-409, 2018.

29. Cheepu M., Muthupandi V., Che W.S., "Improving mechanical properties of dissimilar material friction welds", Applied Mechanics and Materials, Vol. 877, pp. 157-162, 2018. 